\title{
Speed of Adjustment of Capital Structure in Emerging Markets
}

\author{
Bharath Supra*, Vunyale Narender, Nemiraja Jadiyappa, G. P. Girish \\ IBS Hyderabad, A Constituent of IFHE, Deemed to be University, Hyderabad, India \\ Email: "bharathsupra.research@gmail.com
}

Received 16 May 2016; accepted 6 June 2016; published 9 June 2016

Copyright @ 2016 by authors and Scientific Research Publishing Inc.

This work is licensed under the Creative Commons Attribution International License (CC BY). http://creativecommons.org/licenses/by/4.0/

c) (i) Open Access

\begin{abstract}
Speed of Adjustment (SOA) is a concept well studied in the area of capital structure. The concept is premised upon the fact that firms have a target capital structure for the next year and strive to achieve this target; the rate at which it attempts to achieve this target is called SOA. The SOA concept has been successfully applied to evaluate the financing decisions of firms. But most, if not all, of the existing studies in the literature are from the US or the developed world context, which cannot be generalized to emerging markets. This paper is an attempt to highlight the importance of studying the SOA of financing decisions in an emerging market context which provides for a completely different institutional setup. Studies in the direction given by this paper would provide evidence to policy makers and managers to review their existing organizational setup and take necessary action to increase their firm value.
\end{abstract}

\section{Keywords}

Speed of Adjustment, Capital Structure, Emerging Markets, Adjustment Costs, India

\section{Introduction}

Prior to 1950s, research in the finance field was majorly dominated by studies in the areas of Investment and Dividend decision. Modigliani and Miller brought research in financing decisions to the limelight into the sphere of finance. Their paper [1] stated that under certain assumptions, the financing decisions of firms have no impact on the value of the firm. This implies that whether the firm chooses debt or equity in financing its investments had no impact on the value of the firm. Modigliani and Miller [2] refined earlier works and by relaxing the zero tax assumption, argued that the firm value will increase by the present value of tax shields when the financing is through debt in the investments. Interest on debt is tax deductible and provides a benefit (tax shield) that in-

"Corresponding author.

How to cite this paper: Supra, B., Narender, V., Jadiyappa, N. and Girish, G.P. (2016) Speed of Adjustment of Capital Structure in Emerging Markets. Theoretical Economics Letters, 6, 534-538. http://dx.doi.org/10.4236/tel.2016.63059 
creases firm value. In such a case, all firms should go for $100 \%$ debt financing, but this is not true in the real world. Observing this, they argued that along with benefits, debt also has costs in the form of bankruptcy risk. Hence a firm has to trade off between the costs and benefits of financing using debt to get the optimal capital structure. Therefore, optimal capital structure is a level of debt to equity ratio at which firm value is optimum.

The optimum could be due to lower cost of capital and/or due to lower bankruptcy risk. Theoretically, every firm should maintain this optimum level of debt at any point of time [3]. However, due to some market imperfections ${ }^{1}$, firms will not be able to maintain their debt at optimum level. Firms attempt to move towards the optimum either by reducing or by increasing debt or equity at every given opportunity. The rate at which they move towards the optimum leverage is termed as Speed of Adjustment (SOA) of capital structure in the literature. The firm, which has a higher SOA is moving faster to its optimum debt ratio and hence should have a higher value.

The phenomenon of SOA has been studied widely in the western context. However, there exists limited research on SOA in the emerging markets or developing world context. The institutional structure in the emerging markets is different and is witnessed by different organizational setups from the one in developed markets [4]. Hence, the results of the existing literature of SOA are not generalizable to the emerging economies. This study makes an attempt to discuss the research opportunities on SOA of capital structure in the emerging markets (especially India).

The paper is divided into five sections. In Section 2, the methodology used to calculate SOA is presented. Section 3 discusses the institutional differences between emerging and developed economies. Section 4 spells out the ideas for investigating on the SOA of Capital Structure in Emerging Markets, and Section 5 briefs the policy and managerial implication of such studies.

\section{Speed of Adjustment}

Flannery and Rangan [5] have provided a dynamic partial adjustment model to calculate the SOA of capital structure. The study extends the work of Lintner [6] in dividend decisions into the capital structure domain. The Speed of Adjustement (SOA) of capital structure is defined as the rate at which a firm changes its leverage ratio towards its target (optimal) leverage ${ }^{2}$. Firms when adjusting their capital structure and moving towards the optimum will not be able to reach exactly the target capital structure, hence the nature of the adjustment is supported by the argument of market imperfections and adjustment costs as partial adjustment (well known as a partial adjustment model) [7]. In the partial adjustment model, the target leverage is estimated by regressing leverage on the standard determinants of capital structure to estimate the coefficients. The derived coefficients are used to estimate the target capital structure. The estimated target leverage will further be used to estimate the SOA (by comparing actual). The process is explained below.

The partial adjustment model: Target debt ratio,

$$
D_{i, t+1}^{*}=\beta X_{i, t}
$$

where, $D_{i, t+1}^{*}$ is firm $i$ 's desired debt ratio at time $t+1, X_{i, t}$ is a vector of firm characteristics, $\beta$ is coefficient vector.

In a frictionless world, the firms would be able to maintain their capital structures to the optimal or the target capital structure. But in the real world, firms have to deal with adjustment costs, which prevent them from adjusting immediately to the firm's target capital structure. This partial adjustment to the target capital structure can be captured by $\lambda$ in the following equation

$$
D_{i, t+1}-D_{i, t}=\lambda\left(D_{i, t+1}^{*}-D_{i, t}\right)+\delta_{i, t+1}
$$

\footnotetext{
${ }^{1}$ Market imperfections like high transaction costs, undeveloped financial system, and limited credit availability etc., which MM (1958) assumes not to exist and assumes a perfect capital market with no information asymmetry.

${ }^{2}$ Speed of Adjustment $=\frac{\text { Actual Gap covered }}{\text { Initial gap }} ; S O A=\frac{M D R_{i, t+1}-M D R_{i, t}}{M D R_{i, t+1}^{*}-M D R_{i, t}} ;$ where $M D R_{i, t+1}^{*}$ is the target leverage, $M D R_{i, t+1}$ is the leverage in time $(t+1) ; M D R_{i, t}$ is the present leverage of firm (i). Let's assume a firm has its present leverage $M D R_{i, t}=30 \%$; its target leverage, $M D R_{i, t+1}^{*}=50 \%$ and let's say at time $(t+1)$ the firm has its leverage $M D R_{i, t+1}=40 \%$. Then $S O A=\frac{40-30}{50-30}=\frac{10}{20}=50 \%$. This implies that the firm covers $50 \%$ of the gap with the target leverage every year.
} 
On further simplification we arrive at the following equation ${ }^{3}$

$$
D_{i, t+1}=\lambda \beta X_{i, t}+(1-\lambda) D_{i, t}+\delta_{i, t+1}
$$

$\lambda$ is the Speed of Adjustment and $\lambda$ would lie between 0 and $1, X_{i, t}$ is the firm specific variables. By following Rajan and Zingales [8] we include firm size, performance, growth, tangibility and intangibility and Flannery and Rangan [5] Industry median leverage as firm specific variables in our model. The value of $(1-\lambda)$ is expected to stay between zero to one, zero indicating that the firm has made no adjustment and one indicating that the firm has completely adjusted the capital structure to that of the target or optimal capital structure.

\section{India and Institutional Differences}

In the second decade of this century, India has been the world's fourth largest economy [9]. It has a market capitalization of its companies at USD 1.5 Trillion in 2014, which makes it $9^{\text {th }}$ largest country [10]. With economic liberalization starting from 1991, India has been steadily growing and has a largely independent agricultural sector, an expanded industrial base and a steady financial and services sector. Although many developed countries have reeled under some global economic uncertainties, India has managed to consistently maintain its growth rates over and above the averages of the world.

To illustrate the major differences in the financial systems of the developed world (we have taken USA as a representative) and the emerging markets (India) we have plotted below the relative importance of stock market vs banking sector in the economy. The plot is constructed using the ratio of bank credit to the private sector as a percentage of GDP to stock market capitalization as a percentage of GDP. If the ratio is greater than one banking sector dominates the system and if it is less than one stock market are the major source of financing.

As the Graph 1 clearly depicts that in India, stock market dominates the financial system while in the USA banking sector dominates. Should this difference affect SOA? This difference should affect SOA since firms in these markets have differential access to debt and equity.

An emerging economy like India has a very different institutional set up (in terms of legal, financial and regulatory mechanisms) as compared to a developed economy. These institutional differences have given rise to certain market imperfections (like an ill-developed capital markets, slow-bureaucratic administration, passive regulators, etc.) which have compelled firms to find ways to overcome some of these imperfections. There are a few studies which have examined SOA of firms in the developed world context (Flannery and Rangan [5]; Byoun [11]; Lockhart [12]; Oztekin and Flannery [13]; Faulkender et al. [7]; Mukherjee and Wang [14]) but the same phenomenon has not been explored in the developing world context. Such a study would be important as developing countries differ from developed world in financial, legal and tax environment (Khanna and Palepu, [4]; Khanna and Rivkin, [15]). Moreover, the phenomenon of group affiliation and family ownership, which is a major form of ownership of firms, is prevalent in developing countries in general and India in particular.

$$
3
$$

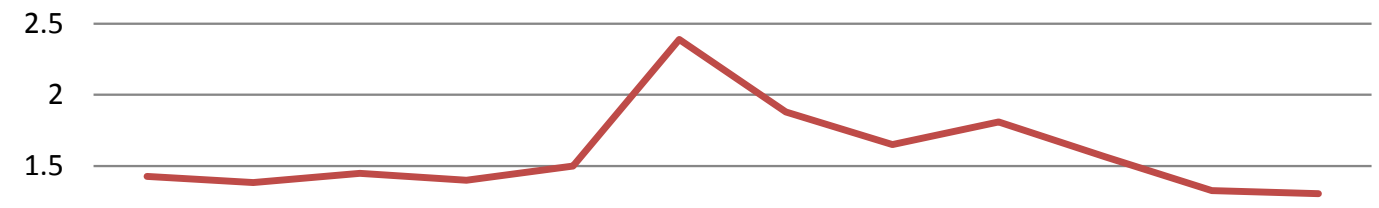

$$
1
$$

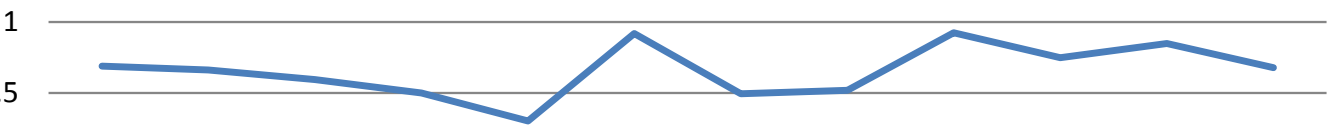

0

$$
\begin{array}{llllllllllll}
2003 & 2004 & 2005 & 2006 & 2007 & 2008 & 2009 & 2010 & 2011 & 2012 & 2013 & 2014
\end{array}
$$

Graph 1. Plot of the ratio of the bank credit to market capitalization of USA and India. Source: World bank.

${ }^{3}$ Each year the firm covers a gap of $\lambda$ between the actual and the target capital structure. Substituting (2) into (3): $D_{i, t+1}-D_{i, t}=\lambda\left(\beta X_{i, t}-D_{i, t}\right)+\delta_{i, t+1} ; \quad D_{i, t+1}=D_{i, t}+\lambda\left(\beta X_{i, t}-D_{i, t}\right)+\delta_{i, t+1} ; \quad D_{i, t+1}=D_{i, t}+\lambda \beta X_{i, t}-\lambda D_{i, t}+\delta_{i, t+1}$. 


\section{Scope for Future Research}

Researchers could focus on the various distinctions in the organizational set up of the emerging economies and firm behaviors' impact on SOA of capital structure. We list few research ideas that could be addressed, though the list is not exhaustive.

\subsection{Impact of Group Affiliation on SOA}

The market imperfections in the emerging countries have given rise to the establishment and growth of groups in the process of industrial development. Group affiliated firms due to their affiliation enjoy access to the group's internal capital market, which the standalone firms have no access to. A standalone firm in need of capital would approach the capital markets. Whereas a group affiliated firm in need of capital would first approach its parent firm or affiliated firms and if the capital requirement is not fulfilled than will approach the external capital markets. This access to the internal capital market of the group should give the group affiliated firm an edge, in terms of faster and cheaper capital, over the standalone firm. Hence it is important to investigate and understand the impact of group affiliation on SOA.

\subsection{Impact of Level of Group Diversification on SOA}

In the emerging markets, group affiliated firms have willfully diversified into a number of sectors of the economy in order to increase their reputation in the capital markets and have a significant influence in the legislative and regulatory mechanisms of the economy. A firm belonging to a highly diversified group should enjoy a better and faster access to the capital markets over the standalone firm, which should affect the rate at which they move towards their target capital structure (SOA). This phenomenon needs to be empirically examined and better understood.

\subsection{Impact of Listing Status on SOA}

Allowing public to be part of the ownership by listing the firm's shares in the stock exchanges not only provides access to the capital from the large pool of retail and institutional investors, also increases the visibility of the firm. The information asymmetry between the investors and managers of the firm is said to be lower for the firms listed on stock exchanges in comparison to that of unlisted firms. Access to the capital markets, higher transparency and market visibility should definitely impact the rate of adjustment of the capital structure of the firm towards its target and hence must be examined.

\subsection{Impact of Macroeconomic Conditions on SOA}

All firms in an economy are affected by the prevailing conditions and expectations in the country. During a good macroeconomic condition, investors (equity and debt) would be willing to provide faster and cheaper capital to firms than in a bad or slow growth economic condition. This should impact the SOA of the firms and hence must be investigated.

\subsection{Impact of Access to Foreign Investments (Debt or Equity) on SOA}

The firms accessing international financial markets for debt or equity (Global Depository Receipts, Foreign Currency Convertible Debentures, External Commercial Borrowings, etc.) raise resources from international sources along with domestic markets. When the firms' access international markets the information asymmetry further reduces with increased disclosure requirements. These firms would be in a position to overcome the impact from unfavorable conditions in the domestic market. This should impact the SOA of the firms and hence be investigated.

\subsection{Impact of Debt Innovation on SOA}

Investability or having the ability to attract investment into a firm is one of the primary determinants of financing decisions. A firm which is willing to innovate its debt indentures should have a higher demand than a firm which uses primitive, plain vanilla debt indentures thereby affecting the SOA of the firm. Hence a motivation for a study. 


\section{Conclusion}

As SOA influences the firm value positively, it is very important to understand this phenomenon. This understanding calls for research in different contexts. Emerging markets provide a context which is not found to be in the developed world and hence research using emerging markets data assumes importance. This research should help investors make better investment decisions. For e.g.: With the knowledge of SOA at the firm level, an investor would able to manage his portfolio better by investing in firms with faster adjustment speeds. Likewise, firm managers would also be interested in knowing the link/relationship between SOA and firm value, which should help them make better decisions. The policy makers are also interested in such a research as it would show the impact of the environment (financial, legal and regulatory) on SOA.

\section{Limitations of the Study}

The study of SOA is based on the trade-off theory of capital structure. But for a thorough analysis the phenomenon must be studied from the perspective of the Agency theory and the Information asymmetry theory. This is the major limitation of this study as we have not considered those perspectives.

\section{References}

[1] Modigliani, F. and Miller, M.H. (1958) The Cost of Capital, Corporation Finance and the Theory of Investment. American Economic Review, 48, 261-297.

[2] Modigliani, F. and Miller, M.H. (1963) Corporate Income Taxes and the Cost of Capital: A Correction. Journal of Finance, 53, 433-443.

[3] Jensen, M.C. and Meckling, W.H. (1976) Theory of the Firm: Managerial Behavior, Agency Costs and Ownership Structure. Journal of Financial Economics, 3, 305-360. http://dx.doi.org/10.1016/0304-405X(76)90026-X

[4] Khanna, T. and Palepu, K. (2000) Is Group Affiliation Profitable in Emerging Markets? An Analysis of Diversified Indian Business Groups. The Journal of Finance, 55, 867-891. http://dx.doi.org/10.1111/0022-1082.00229

[5] Flannery, M.J. and Rangan, K.P. (2006) Partial Adjustment toward Target Capital Structures. Journal of Financial Economics, 79, 469-506. http://dx.doi.org/10.1016/j.jfineco.2005.03.004

[6] Lintner, J. (1956) Distribution of Incomes of Corporations among Dividends, retained Earnings, and Taxes. The American Economic Review, 46, 97-113.

[7] Faulkender, M., et al. (2012) Cash Flows and Leverage Adjustments. Journal of Financial Economics, 103, $632-646$. http://dx.doi.org/10.1016/j.jfineco.2011.10.013

[8] Rajan, R.G. and Zingales, L. (1995) What Do We Know About Capital Structure-Some Evidence From International Data. The Journal of Finance, 50, 1421-1460. http://dx.doi.org/10.1111/j.1540-6261.1995.tb05184.x

[9] The World Bank (2016) India Overview. http://www.worldbank.org/en/country/india/overview

[10] The World Bank (2016) Market Capitalization of Listed Domestic Companies (Current US\$). http://data.worldbank.org/indicator/CM.MKT.LCAP.CD

[11] Byoun, S. (2008) How and When Do Firms Adjust Their Capital Structures toward Targets? Journal of Finance, 63, 3069-3096. http://dx.doi.org/10.1111/j.1540-6261.2008.01421.x

[12] Lockhart, G.B. (2014) Credit Lines and Leverage Adjustments. Journal of Corporate Finance, 25, $274-288$. http://dx.doi.org/10.1016/j.jcorpfin.2013.12.011

[13] Öztekin, Ö. and Flannery, M.J. (2012) Institutional Determinants of Capital Structure Adjustment Speeds. Journal of Financial Economics, 103, 88-112. http://dx.doi.org/10.1016/j.jfineco.2011.08.014

[14] Mukherjee, T. and Wang, W. (2013) Capital Structure Deviation and Speed of Adjustment. Financial Review, 48, 597615. http://dx.doi.org/10.1111/fire.12017

[15] Khanna, T. and Rivkin, J.W. (2001) Estimating the Performance Effects of Business Groups in Emerging Markets. Strategic Management Journal, 22, 45-74. http://dx.doi.org/10.1002/1097-0266(200101)22:1<45::AID-SMJ147>3.0.CO;2-F 